LA-UR- $/ 1-02378$

Approved for public release;

distribution is unlimited.

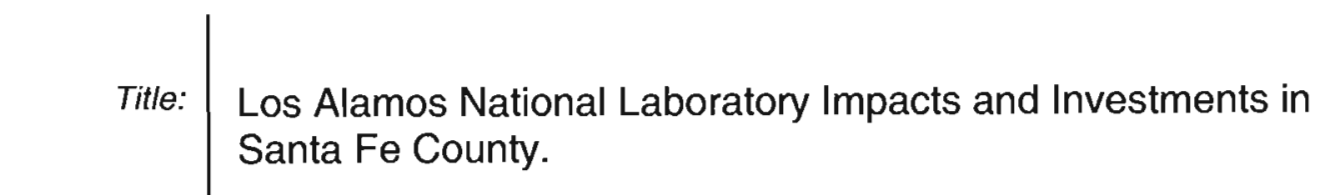

\begin{tabular}{c|l} 
Author(s): & Johnnie Martinez \\
Intended for: & Presentations to Community Leaders \\
Prestion
\end{tabular}

\begin{tabular}{c|c} 
Author(s): & Johnnie Martinez \\
Intended for: & Presentations to Community Leaders
\end{tabular}

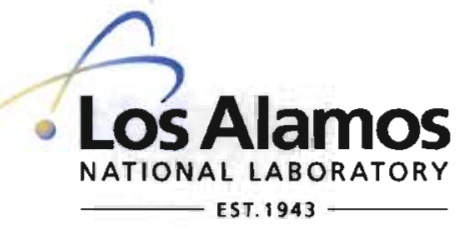

Los Alamos National Laboratory, an affirmative action/equal opportunity employer, is operated by the Los Alamos National Security, LLC for the National Nuclear Security Administration of the U.S. Department of Energy under contract DE-AC52-06NA25396. By acceptance of this article, the publisher recognizes that the U.S. Government retains a nonexclusive, royalty-free license to publish or reproduce the published form of this contribution, or to allow others to do so, for U.S. Government purposes. Los Alamos National Laboratory requests that the publisher identify this article as work performed under the auspices of the U.S. Department of Energy. Los Alamos National Laboratory strongly supports academic freedom and a researcher's right to publish; as an institution, however, the Laboratory does not endorse the viewpoint of a publication or guarantee its technical correctness. 


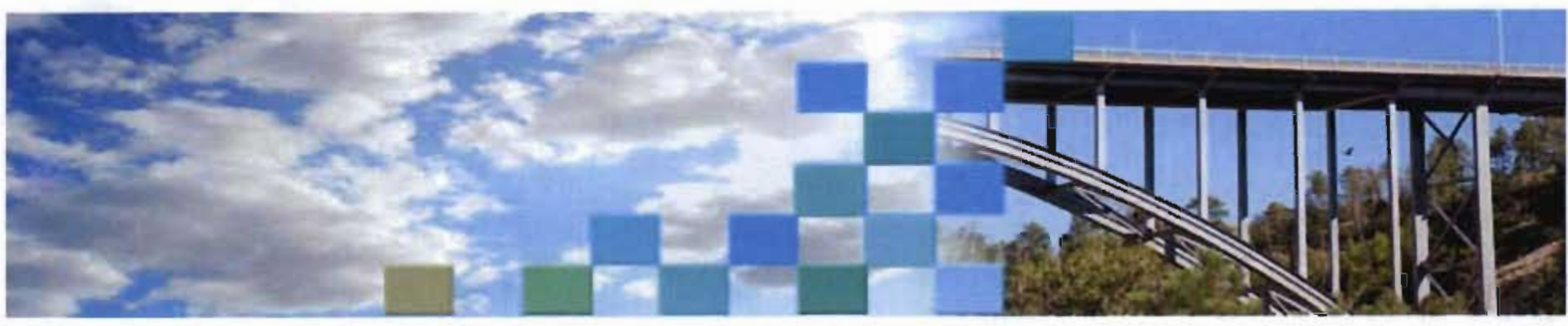

\section{Los Alamos National Laboratory Impacts and Investments in Santa Fe County}

Santa Fe County is home to 2,357 LANL employees and contractors. LANL's estimated economic impact in Santa Fe County in FY09 was $\$ 672 \mathrm{M}$ (based on employee salaries and benefits, indirect and induced impacts, and retirement benefits as determined in a study conducted by the University of New Mexico's Bureau of Business and Economic Research).

In FY10, LANL purchased $\$ 26,448,987$ in products and services from Santa Fe County businesses.

Santa Fe is one of seven northern New Mexico counties identified in the Lab's maintenance and operations contract with NNSA that is targeted for education, economic development, and charitable giving programs through the LANS, LLC Community Commitment Plan.

\section{Education}

The Laboratory's goal in education is to enhance regional Science Technology, Engineering, and Mathematics (STEM) education and enrichment initiatives through Workforce Development, Student Internships, Teacher and Faculty Professional Development, and Public Understanding of Science.

Employee involvement: In FY10, LANL employees gave 1,340 hours to various STEM initiatives in Santa Fe County, and students and teachers from the following Santa Fe schools participated in one or more of LANL's regional education programs. 


$\begin{array}{ll}\text { - } & \text { Agua Fria Elementary } \\ \text { - } & \text { Capshaw Middle School } \\ \text { - } & \text { Carlos Gilbert Elementary } \\ \text { - } & \text { Edward Ortiz Middle School } \\ \text { - } & \text { Gonzales Elementary } \\ \text { - } & \text { Nambe Pueblo Headstart } \\ & \text { Pojoaque Valley Schools }\end{array}$

$\begin{array}{ll}\text { - } & \text { Santa Fe Indian School } \\ \text { - } & \text { St. Michaels Schools } \\ \text { - } & \text { Santa Fe High School } \\ \text { - } & \text { Sweeney Elementary } \\ \text { - } \quad \text { Tesuque Pueblo Day School } \\ \text { - Turquoise Trail Elementary } \\ \quad \text { Wood Gormley Elementary }\end{array}$

Los Alamos Employees Scholarship Fund: Santa Fe County

The 2011 Los Alamos Employees Scholarship Fund Gold recipient is Hannah McMurray from Santa Fe High School. The amount of the scholarship is \$20K. Additionally, 20 students from Pojoaque, St.

Michael's High School, Desert Academy, Santa Fe High School, Santa Fe Preparatory, Capital High School, Monte Del Sol Charter School, and Waldorf Academy schools were awarded a total of $\$ 113 \mathrm{~K}$ in academic scholarships.

Previous scholarship funds provided to Santa Fe County students:

$\begin{array}{ccc}-\quad \$ 51,000 \text { in } 2007 & \bullet & \$ 69,000 \text { in } 2009 \\ -\quad \$ 298,000 \text { in } 2008^{*} & \bullet & \$ 64,000 \text { in } 2010\end{array}$

United Way of Santa Fe County is our employee-giving campaign partner in that county. That organization's Children's Project programs Include:

- $\quad$ Pre-K for four year olds: A kindergarten readiness program.

- $\quad$ The Pre-K Graduate Institute: A support program for parents to help their children with $\mathrm{K}-3$ education activities.

- $\quad$ Out-of-school-time partnership: An afterschool program for elementary students.

- $\quad$ Community Schools: This program provides students with physical and mental health services at school sites, as well as evening adult education classes, and family activities.

LANL/LANS Contributions to the Santa Fe Children's Project through United Way of Santa Fe County:

\begin{tabular}{l} 
- $\quad \$ 141,463$ in 2007 \\
- $\quad \$ 136,171$ in 2008 \\
\hline 140,391 in 2009
\end{tabular}

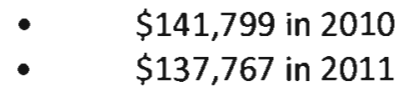

Bradbury Science Museum: Science education activities conducted by our Museum reached 1,324 Santa Fe County students in 2010.

New! Northern New Mexico Inquiry Science Initiative: A regional program to improve K-6 student academic achievement in science, math and literacy, meeting or exceeding the state requirements. Partners include: Santa Fe, Española, Peñasco, Los Alamos, and Mesa Vista Public Schools, Los Alamos National Laboratory Foundation, and LANL. The program provides teacher/principal/superintendent training and professional and administrative support for using inquiry-based, hands-on science kits. Participating Santa Fe elementary schools include Amy Biehl, Aspen, and Salazar. 
Santa Fe Community College: LANS invests $\$ 100 \mathrm{~K}$ annually to support the College's Advanced Technologies program. The program has concentrations in Biofuels, Facilities Technology, Green Building, Solar Energy, and Water Conservation.

Student Support: LANL Laces is a year-round Laboratory employee-giving program designed to purchase shoes for children who need them. Students from Kaune Elementary School in Santa Fe received 35 pairs of shoes in 2010.

School Supply Drive/Back Pack Challenge: In 2010, Lab employees filled 490 back packs with school supplies for Santa Fe County students to help prepare them for the school year. Santa Fe organizations that partnered with LANL to help students included the Adelante K-12 Homeless Program; Boys and Girls Clubs in Santa Fe, Chimayo, Pojoaque, and Santa Cruz; and the Wings for Hope community organization. 


\section{Economic Development}

The Laboratory has been involved with Santa Fe business community as a member and strategic partner with the Santa Fe Chamber of Commerce since 1990, Santa Fe Business Incubator, Santa Fe Complex, Northern NM Chapter of NM Technology Council, and High Desert Discovery District.

Northern New Mexico Connect is the principal economic development investment of Los Alamos National Security, LLC and Los Alamos National Laboratory. Its collection of coaching, networking, research, technical assistance, and investment activities are designed help businesses reach the next level of success and create an entrepreneurial culture in northern New Mexico.

Since 2006, NNM Connect programs have assisted more than 70 companies in Santa Fe:

Venture Acceleration Fund - Ten Venture Acceleration Fund Awards were given to Santa Fe businesses commercializing new technology or technology business start-ups: CIVA, ApJet, Knowledge Reef, Packet Analytics, Veeyzon, Retriever Technologies, Elemetrics, Mesa Tech International, and SimTable.

Springboard - Eleven Santa Fe companies received expert coaching on strategic decisions: Strategic Analytics, PDM (Precision Data Mining), Doxecelarate, Particle Pipes, Healthy Buildings, EarthStone International, Cedar Mountain Solar, VariStreamTV, SimTable, Eldorado Biofuels, and Planet Forward.

Market Intelligence - Analysts provided customized market research and data sources for 23 Santa Fe entrepreneurs: Adora Fibers, CG Higgins Confections, Cutting Edge Catalog, Deep Web Technologies, El Dorado Biofuels, Firefly, Get Down to Earth Landscapes, Good Water Company, Jerome Capital, Marty's Meals Mayfield Media, Mesa Photonics, New Earth Orchids, Planet Forward, Prull Builders, Retriever Technology, Roofcare, Rostami Motors, Southwest Sciences, Star Cryoelectronics, Technology Solution $N M$, Varistream $T V$, and ZuluBrew.

Education and Networking - More than 20 networking and education events have been held at Santa Fe Complex, Santa Fe Business Incubator, Santa Fe Farmers Market, and other Santa Fe locations.

New Mexico Small Business Assistance - Laboratory staff helped more than 50 companies in Santa Fe County solve their technical challenges: Acoustic Biosystems, Ambient Pixel, LLC AMI Corporation, APJeT, Aqua Del Cielo, Atmocean Inc, Better Music Boxes, BioMagViz, Bluenergy Solarwind Inc, Cedar Mountain Solar, Center for Orthopedic and Sports Performance Research, Centric Management Services, Chapman Realty, Chuck Higgins, Conscious Health Decisive Systems, Dougherty Real Estate, Ek Systems, Eldorado Biofuels, LLC Energy Matter Conversion Corporation, Glorieta Geoscience, Good Water Company, Healthy Buildings Wood Chip Block, Heilbron Associates, Intermodal International \& Associates, Kreger Design Build, Lau-Nahmias, Los Atrevidos, Mar Oil \& Gas Corporation, Mesa Tech International, Metallicum, Mountain Hound, National Water Services, Native Son Builders, Palo Santo Designs, Paynes Nurseries \& Greenhouses, Pointy Triangle, Rancho Nambe Road Safety Technologies, S. Silber \& Associates, Sierra Aviation, Simtable, STAR Cryoelectronics, Tierra Merced, Trusty \& Associates P.A., Vista Therapeutics, Vitre International,VM Technology, Walton Chapman Building Company, Steve Warshawer, Wartell Enterprises, and Watermatters.

LANL:CPO - Santa Fe County Impacts 


\section{Community Giving}

Los Alamos National Laboratory is committed to giving back to its northern New Mexico neighbors. Our Community Programs Office manages a variety of giving programs to provide opportunities for LANL employees and retirees to make gifts of time, talent, and money to improve the quality of life of our neighbors.

\section{LANL Employee Giving Campaign}

LANL/LANS Contributions to eligible nonprofit organizations in Santa Fe County (other than the Santa Fe Children's Project as noted above):
- $\quad \$ 80,028$ in 2007
- $\quad \$ 58,128$ in 2008
- $\quad \$ 78,201$ in 2010
- $\$ 68,290$ in 2009
- $\quad \$ 93,233$ in 2011

LANS Community Grants - One-time LANS, LLC grants to eligible nonprofit organizations
- $\quad 2008-\$ 92,105$
- $2009-\$ 19,000$

LANL Volunteer Recognition Events - LANS, LLC donations to organizations supported by LANL employee/retirees

- $\quad 2007-\$ 8,626$

- $\quad 2008-\$ 15,652$

- $2009-\$ 14,624$

Los Alamos National Laboratory Drives in 2010:

- Holiday food campaign - LANL employees provided 160 food baskets and turkeys to St. Elizabeth Shelter, Wings for Hope, and St. Vincent de Paul programs.

- $\quad$ Holiday gift drive - LANL employees donated 495 holiday gift tags to Santa Fe children in partnership with the Chimayo, Santa Fe, and Santa Cruz Boys \& Girls Clubs; Wings for Hope; and the Santa Fe Office of the New Mexico Children, Youth and Families 